\title{
Has the Surplus of Women over Men Driven the Increase in Premarital and Casual Sex among American Young Adults?
}

\author{
Paula England
}

Published online: 18 October 2012

(C) Springer Science+Business Media New York 2012

Sex before marriage has gotten more frequent and more casual since the 1970 s, and more of it than previously is outside of even the limited commitment of a relationship. Average age at marriage has gotten later, and there is more childbearing outside marriage. Regnerus argues that men want sex more than women, and that, while some women want sex with no commitment, it is more important to the average woman than to the average man that sex be combined with an affectionate relationship and some commitment. If he is correct about these average sex differences in preferences, then changes in recent decades seem counter to what women would have wanted. Of course, with the advent of the pill, and women's increasing careerism, Regnerus recognizes correctly that women themselves may want uncommitted sex when they are young more than in previous eras. Yet he believes that patterns have changed much more toward sex without commitment than women would have preferred.

Regnerus argues that one cause of these changes is changing sex ratios. I agree with Regnerus that, in some subpopulations skewed sex ratios may have strong effects on sexual behavior. However, I do not agree that sex ratio changes explain much of the dramatic society-wide changes in sexual and relational behavior that have been going on for 50 years or more. As I'll show, at the society-wide level, there has simply not been enough change in the sex ratio to have an appreciable effect.

The "sex ratio" in a population is the ratio of men to women (it is conventional to put men in the numerator). The basic notion in the sex ratio theory is that, the higher the ratio of men

\section{P. England $(\square)$}

Department of Sociology, New York University,

295 Lafayette St.,

New York, NY 10012, USA

e-mail: pengland@nyu.edu to women, the more women have the power to get what they want in heterosexual partnerships. Or, equivalently, the lower the ratio of men to women, the more men have power to get what they want in such partnerships. This thesis was put forward by sociologists (Guttentag and Secord 1983); its basic logic can be found in several social science perspectives, such as bargaining models in economics based on game theory, and social psychologists' exchange (or "power-dependence") theory. A idea is that, within a relationship of any type, Partner A has more power to get what she or he wants from Partner B if A has more alternatives outside the relationship. Because the sex ratio affects one's number of alternative partners outside the relationship, it affects power within any given relationship. In common sense terms, if you know you can be easily replaced, but you would have a hard time finding another partner, you are likely to be more accommodating to whatever your partner wants. As distasteful as it may be to think that intimate realms are affected by such market forces, the sex ratio theory strikes me as a reasonable hypothesis. So I read Regnerus' marshaling of the evidence for the theory with interest.

As evidence that sex ratios matter, Regnerus discusses his analysis with Uecker drawing on a survey of college women. The women were spread across a large number of colleges and universities, and the authors obtained the sex ratio in each of these schools. In a statistical model with many factors held constant, they found that women attending schools with a lower ratio of men to women were less likely to have a boyfriend but more likely to have had sex ever, and to have had sex recently. If women in schools with less men per woman had been less likely to have a boyfriend and less likely to have sex, we could conclude that there just weren't enough men available, so some women had to forego either relationships or sex. But the fact that women have more sex and fewer relationships when there are fewer men available suggests to the authors that, when men are scarce, they are more able to get women to "give them" sex 
without the commitment of a relationship. Regnerus also cites an unpublished study using the National Longitudinal Survey of Freshmen finding that young women on campuses with a lower ratio of men to women are more likely to have had sex during their freshman year, and a study by economists showing that high schools with a lower ratio of boys to girls feature more kids having sex. Moreover, he discusses research suggesting that the dramatic increases in incarceration in recent decades have disproportionately drained black communities of men, and that this may help explain patterns of relations between black men and women that entail high rates of childbearing outside marriage or other committed unions. Not all available evidence supports the idea that uncommitted sex is more prevalent in subpopulations where the ratio of men to women is lower, ${ }^{1}$ but the evidence is substantial.

While the sex ratio theory may well have some merit in explaining differences between sub-populations in sexual behavior, this does not necessarily imply that the theory can explain society-wide trends over time in such behavior. But this is what Regnerus suggests. I believe that, at least among whites, changes in sex ratios can't explain the trends because the sex ratio for the population as a whole hasn't changed that much. I used Census data to compute the percent men constituted of U.S. white ${ }^{2}$ residents age 18 to 25 for each decennial Census date since 1940. The percent was between $49 \%$ and $51 \%$ in each of 1940, 1950, 1960, 1970, 1980, 1990, 2000, and 2010. There are only trivial disparities from an equal number of men to women, and there is no systematic downward trend in the percent. Yet, no one can doubt that white youth and young adults have experienced dramatic changes in sexual and relational behavior since 1960. Premarital sex and cohabitation before marriage have become normative (Regnerus and Uecker 2011; Smock 2000), teen sex has increased (although rates have inched back downward since sometime in the 1980s) (Martinez et al. 2011:5), at least a subset of high school and college students are engaged in a casual "hookup" culture

\footnotetext{
${ }^{1}$ An unpublished analysis by one of my students, using data from an online survey I conducted at 21 colleges and universities does not support the sex ratio theory. With numerous controls, Mausolf (2012) finds that women in schools with a lower ratio of men were less likely to have ever had sex, or to have had more than five intercourse partners. For men, sex ratio of the school had no significant effect on these outcomes. The sex ratio thesis predicts more sex for men and women where the ratio of men to women is lower, if we assume that men want the type of sex that is occurring more than women; thus, the findings don't support the sex ratio thesis for either men or women. (If we assume women and men are equally interested in the types of sex that are occurring, the theory predicts no differences.) For a description of the data set, see Armstrong et al. (2012).

${ }^{2}$ The Census includes incarcerated men, who aren't really available as partners, and the proportion of men incarcerated has risen since 1980, but among whites the rates are sufficiently low that it should not affect the sex ratio much (see note 3 ).
}

(England et al. 2008), and nonmarital childbearing has increased (Child Trends 2012). Clearly, the causes of these shifts are something other than changes in the sex ratio since the sex ratio hasn't changed nontrivially, at least for whites.

In addition to the bold claim that society-wide trends in sexual behavior resulted in part from changing sex ratios, I also take Regnerus to be offering the more modest claim that changes toward more uncommitted sex among college students and college graduates are explained by changes in the sex ratio among those attending and graduating from college. At first glance, this seems a plausible hypothesis because, as Regnerus points out, nation-wide, women have gone from being a small minority of those graduating from college to a sizeable majority (57\%). It makes sense that college students partner mostly with each other, and we know that college graduates generally marry other college graduates (Schwartz and Mare 2005), so college attenders could be a relatively closed market affected by changes in its sex ratio.

But there is no evidence for this link, and I doubt that the trend toward sexual liberalization of the behavior of college students and college graduates is because the ratio of men has gone down. Here's why: A consequence of the fact that the ratio of young men to women has gone down in college and among graduates is that the ratio of men to women must have gone up among those not going to college. ${ }^{3}$ Although Regneris does not draw out this implication, under his version of the sex ratio theory, this would imply that the trend would be away from uncommitted sex and nonmarital childbearing among the less educated. But there is no evidence whatsoever for this. Kids not going to college start sex slightly earlier than those who go to college; thereafter I see little evidence that their sexual behavior is different than that of college-going kids, but they use birth control less consistently, have more unintended pregnancies, and are more likely to have children outside of marriage (England et al. 2011). It is possible that the levels of such behavior are higher among the disadvantaged but that their rates of change toward such behavior are more modest than for those who graduate from college; this would be consistent with a net effect of sex ratios. I have never seen any evidence of this, however.

For explanations of the society-wide changes in sexual and relational behavior, we need to look elsewhere than to

\footnotetext{
${ }^{3}$ If increases in incarceration were sufficiently dramatic for noncollege-going men, then it would be possible for the ratio of men to women among this group to go down even while fewer men than women attend college. For white men 20-40 years of age who never attended college, the proportion of men incarcerated remains fairly modest, although it did increase from 0.009 to 0.032 from 1980 to 2000; by contrast, the proportion for black men 20-40 who never attended college went from 0.06 to 0.17 across the same period (Western 2006:17).
} 
the sex ratio. Many sociologists say, "It's the economy, stupid!" They believe that the key to the trends in nonmarital sex and childbearing is in the reduced economic opportunity men face, rendering them unmarriageable, and encouraging nonmarital childbearing. I disagree with this assessment, because, for both whites and blacks, childbearing before marriage has increased steadily starting back as early as cohorts born in 1925, whose first births were in the 1940s (England et al. 2012). This increase has gone on in good and bad economic times. I believe that there has been a liberalization for about 50 years in sexual behavior that is caused neither by declining economic opportunity nor changing sex ratios. I'm not sure what the cause is, but it is an interesting question for research. This permission for sex outside marriage, and, for some, even outside a monogamous relationship, has happened in all social classes, but, in my view, has different results by social class because of differences in how motivated and able young adults are to use contraception consistently (England et al. 2011). For those privileged enough to go to and complete college, uncommitted sex often occurs before marriage, which is later than previously, but most all marry eventually, and most childbearing remains in marriage. The less privileged often lack meaningful social roles other than parenthood, have less opportunity to learn the self-regulation needed to use birth control consistently, hold more negative views about abortion, and can less well afford abortions. All these forces combine with new cultural beliefs - in all social classes - that couples should be economically "set" before marriage, and the result for the disadvantaged is high rates of childbearing outside of marriage.

\section{Further Reading}

Armstrong, E., England, P., \& Fogarty, A. 2012. Accounting for Women's Orgasm and Sexual Enjoyment in College Hookups and Relationships. American Sociological Review, 77(3), 435-462.
Child Trends. 2012. Percentage of Births to Unmarried Women. Retrieved from www.childtrendsdatabank.org/?q=node/196. Last update: March, 2012.

England, P., McClintock, E., \& Shafer, E. F. 2011. Birth Control Use and Early, Unintended Births: Evidence for a Class Gradient. In M. Carlson \& P. England (Eds.), Social Class and Changing Families in an Unequal America (pp. 21-49). Stanford: Stanford University Press.

England, P., Shafer, E. F., \& Fogarty, A. C. K. 2008. Hooking Up and Forming Romantic Relationships on Today's College Campuses. In M. Kimmel \& A. Aronson (Eds.), The Gendered Society Reader (3rd ed., pp. 531-547). New York: Oxford University Press.

England, P., Wu, L.L., \& Shafer, E.F. 2012. Cohort Trends in Premarital First Births: What Role for Premarital Conception versus the Retreat From Marriage. Unpublished paper, New York University, Department of Sociology.

Guttentag, M., \& Secord, P. F. 1983. Too Many Women? The Sex Ratio Question. Beverly Hills: Sage.

Martinez, G., Copen, C.E., \& Abma, J.C. 2011. Teenagers in the United States: Sexual activity, contraceptive use, and childbearing, 2006-2010 National Survey of Family Growth. National Center for Health Statistics. Vital Health Stat 23(31).

Mausolf, J.G. 2012. Environmental Hookups: The Effects of School Social Environment and the College Hookup Scene. Unpublished Senior Honor's Thesis, Department of Sociology, New York University.

Regnerus, M. 2012. Mating Market Dynamics, Sex-Ratio Imbalances, and Their Consequences. Society, December 2012.

Regnerus, M., \& Uecker, J. 2011. Premarital Sex in America: How Young Americans Meet, Mate, and Think about Marrying. New York: Oxford University Press.

Schwartz, C. R., \& Mare, R. D. 2005. Trends in Educational Assortative Marriage From 1940 to 2003. Demography, 42, 621-46.

Smock, P. 2000. Cohabitation in the United States: An Appraisal of Research Themes, Findings, and Implications. Annual Review of Sociology, 26, 1-20.

Western, B. 2006. Punishment and Inequality in America. New York: Russell Sage.

Paula England is Professor of Sociology at New York University. She is interested in gender and family patterns. Her recent research focuses on class differentials in nonmarital births and unplanned pregnancy, and on "hooking up" among college students. 